\title{
The Hypertensive Patient and the Commitment to Comply with Medical Treatment
}

\author{
El paciente hipertenso y su compromiso con el cumplimiento del tratamiento medico
}

\author{
Nancy Cerón Delgado, Jesús Carlos Ruvalcaba Ledezma, Juan Carlos Paz Bautista \\ Área Académica de Medicina del Instituto de Ciencias de la Salud \\ Universidad Autónoma del Estado de Hidalgo, México.
}

Corresponding Author: Nancy Cerón Delgado, Instituto de Ciencias de la Salud, Ex Hacienda la Concepción s/n Carretera, PachucaActopan, Tilcuautla. Pachuca Hidalgo, México.C.P.42160,Tel (044) 7711245692,E-mail: nancy_724@hotmail.com

\begin{abstract}
:
The Systemic Arterial Hypertension (SAH), one of the major chronic non-communicable diseases that afflict modern life, is a public health problem that disproportionately affects developed and developing countries, which can usually start at a reproductive age, it also shortens life expectancy and its lack of control can increase a precarious quality of life. However, despite the fact that the association between compliance with pharmacological treatment and the greater degree of control of chronic diseases is currently known, the way patients face their disease, due to the fact that hypertension rarely produces symptoms, lessens the fulfillment of their treatment due to ignorance, oblivion or little interest on behalf of the doctor or the null capacity in this problem of public health that leads to have no control of blood pressure readings. This is why the behavior of people can play an important role in this change, thereby achieve reducing the main complications, and even have a higher quality of life, if the patient is duly committed to the new lifestyle that the disease demands.
\end{abstract}

Key words:

Compliance, Adherence, Hypertension, Patient, Medical treatment

\section{Resumen:}

La Hipertensión Arterial Sistémica (HTA), una de las principales enfermedades crónicas no transmisibles, que aquejan la vida moderna, es un problema de salud pública que afecta desproporcionadamente a países desarrollados y en vías de desarrollo, el cual generalmente se puede iniciar en la edad reproductiva, además acorta la esperanza de vida y su descontrol puede aumentar una calidad de vida precaria. Sin embargo a pesar de que actualmente es conocida la asociación entre el cumplimiento del tratamiento farmacológico y el mayor grado de control de las enfermedades crónicas, la forma en que los pacientes afrontan su enfermedad, por el hecho de que la hipertensión arterial rara vez produce síntomas, hace que se vea mermado el cumplimiento de su tratamiento por ignorancia, olvido o por el hecho de poco interés del médico o la nula capacidad en este problema de Salud Pública que hace que no se logre el control de las cifras de presión arterial. Es por ello que el comportamiento de las personas podrá desempeñar un papel importante en este cambio y con ello lograr incidir en disminuir las principales complicaciones e incluso tener una mayor calidad de vida, si se compromete el paciente adecuadamente al nuevo estilo de vida que exige la enfermedad.

\section{Palabras Clave:}

Cumplimiento, adherencia, hipertensión, paciente

\section{Introduction}

The Systemic Arterial Hypertension (SAH), one of the main noncommunicable chronic diseases, is a public health problem that disproportionately affects developed and developing countries. $^{1} \quad$ Epidemiological studies have identified cardiovascular diseases (CVD) as the leading cause of morbidity and mortality in developed countries. ${ }^{2}$

The 2012 National Health and Nutrition Survey (ENSANUT) estimates that in Mexico there are 22.4 million adults, of 20 years old or more of age that suffer from hypertension, of whom only 11.2 million have been diagnosed by a physician. Of these
Mexicans who have been diagnosed and who are under treatment, 5.7 million had blood pressure readings that can be considered adequate, that is, they maintain their illness controlled. ${ }^{3}$ Early detection of hypertension, appropriate treatment, and sustained blood pressure control lead to important health and economic benefits. ${ }^{4}$ The increase in health costs due to non-compliance or changes in the medication originally prescribed has been calculated in $20 \%$ per capita per year. ${ }^{5}$ On the other hand, it can generate losses from the personal, social and family perspectives. The patient can present complications and sequelae carrying physical and psychological suffering that could be avoided, as well as 
irreversible and progressive limitations that significantly affect the quality of life. In the labor sphere, it may imply a readjustment of goals and purposes that affect economic life and often interfere in the communication with other people or in the roles and responsibilities that the person has in the family. ${ }^{6}$

Recognition and concern about the fact that patients often fail in following medical prescriptions from health professionals go back to ancient times. Hippocrates stated in some of his writings that some patients lied to the doctor when they were questioned if they had taken the indicated medicines; in fact, in the Hippocratic corpus the errors and lies of patients are already mentioned, and how they were considered as an obstacle for the patient's recovery. ${ }^{7}$

The association between the compliance with pharmacological treatment and the major level of control of chronic diseases is currently known, and as a consequence, a lower or higher cardiovascular morbidity and mortality. ${ }^{8}$

From this point of view, the control of hypertension and the way in which patients face their disease is a key element when preventing subsequent risks. In addition, SAH rarely produces symptoms in the early stages and, in many cases, is not properly diagnosed, so the patient may not be aware that he or she is suffering from any type of illness. ${ }^{9}$

However, people's behavior can play an important role in this evolution and even extend their lives, if they adhere properly to the lifestyle demanded by the disease. Currently, adherence to the required lifestyle is of great importance in the treatment of chronic diseases, since the non-compliance of it makes ineffective the prescribed treatment, increasing morbidity and mortality, as well as the costs of hospital care. ${ }^{10}$ This makes us understand that an important aspect in patients with arterial hypertension is the commitment to comply with the treatment. ${ }^{11}$ The compliance with medical treatment refers to the degree of success a patient has in carrying out preventive or treatment recommendations given by a health professional. The noncompliance, on the other hand, refers to the ignorance, oblivion, or lack of understanding of the regimen suggested by the physician. In spite of being a common practice is not much detected by health professionals, therefore one of the biggest problems that health professionals deal with is how to maximize compliance with therapeutic plans in patients. ${ }^{12}$ Many hours and economic resources are spent every year to improve the efficacy and safety of medicines, as well as to implement medical care protocols; however, very few resources are devoted to whether the patient takes them or not, and it is of little use to have excellent treatments if the patient does not follow the medical recommendations correctly. ${ }^{10}$

Adherence to treatment has been defined in different ways, but mainly as compliance or follow-up of medical instructions. Over the years, this reductionist connotation has been overcome, giving an increasingly active role to the patient. In addition, adherence to other non-pharmacological aspects that are part of the treatments (such as the change of eating habits, physical activity, handling of emotions, etc.) has started to be considered important. ${ }^{13}$

Thus, despite the efforts to control hypertension, adherence to pharmacological treatments and non-pharmacological recommendations is very low, which makes it difficult to reduce blood pressure and maintain it at controlled levels. ${ }^{13}$

\section{Definition of compliance with medical treatment}

There is currently no agreement on a particular definition of the concept of therapeutic adherence, usually we can find in literature concepts like: compliance, adherence, cooperation, collaboration, observance, therapeutic alliance, follow-up, adhesion and concordance. ${ }^{14}$

According to $\mathrm{Boza}^{15}$, compliance with treatment is "the patient's remarkable understanding of treatment needs and their different possibilities, followed by appropriate action." For Galperin ${ }^{16}$, it is "the extent to which the patient responds to the medical indications and makes them his or her own, having different motivations on the part of the patient that explain the degrees of adherence to the different indications." Haynes ${ }^{17}$ states that it is "the degree to which a patient's behavior, in relation to medication intake, diet follow-up, and lifestyle modification, coincide with the instructions provided by the physician". ${ }^{2,15-18}$ However, one can understand as compliance: The extent to which the patient assumes the rules or advices given by the physician or health personnel, from the point of view of both recommended habits or lifestyle and the prescribed pharmacological treatment, showing the degree of coincidence between the instructions given by the professional and their follow-up on behalf of the patient, assumed after a completely reasoned decision. ${ }^{8}$

\section{Epidemiology of compliance with the therapy}

One of the main factors associated with the control of hypertension is the therapeutic adherence, or compliance. Control is of the utmost importance, since the reduction of complications depends on it; however, one third of the patients do not know that they have the disorder, $67 \%$ know they have the disorder, but only half of them have control on it. ${ }^{19}$

It is common that studies on pharmacological compliance in hypertension report that $25.6 \%$ of all hypertensive patients in the world are noncompliant patients. While more than half of people have partial adherence and more than one third are fully adherent patients, this is similar to what is found in other reports using therapeutic adherence measurement instruments. ${ }^{8,19}$

On the other hand, the World Health Organization (WHO) estimates that in the case of hypertension, the percentage of patients complying with the therapeutic regimen is only $27 \%$ in Gambia, $46 \%$ in China and $51 \%$ in the United States. While those with good adherence, the percentage of controlled patients reaches $96 \% .^{10}$

\section{Etiology of compliance and non-compliance with medical treatment}

There are many causes attributed to the manifestations of this problem. Compliance with medical treatment requires multiple factors to achieve a positive impact on the quality of life of hypertensive patients. There are different authors, dedicated to the study of the subject, that suggest the existence of a large group of influential factors in the conduct of compliance or noncompliance of medical treatment involving components of a psychosocial and medical nature (characteristics of the disease and the treatment per se) and the relationship physician-patient. Also personal, economic factors, which favor noncompliance and consequently the comorbidities that affect the quality of life of the patients. ${ }^{20-21}$

Determining factors of therapeutic compliance 
1. Socioeconomic factors. In rural areas, less effort has been made to determine the magnitude of the problem. In this case, the majority of the population is engaged in land-related activities in an unfavorable physical environment, living in harsh, poorly communicated areas within a framework of notable scarcities like: poverty, illiteracy, unemployment, remoteness of the health center, high costs of transportation and medication, lack of effective social support networks, unstable living conditions, changing environmental situations, culture and popular beliefs about the disease and its treatment and dysfunctional families. ${ }^{14-22}$

2. Factors related to health care systems. The detection and control of these patients should be the responsibility of the primary health care level, whose functions include introducing them to the health care system, start early treatment, prevent complications and have the capacity to timely refer them to other levels of care. However we find something different as they are: poorly developed health services with inadequate or non-existent reimbursement of health insurance schemes, incomplete drug distribution systems, lack of knowledge and training of health care personnel for the control of chronic diseases, heavy workload of the staff, lack of incentives and feedback on their performance, short consultations, poor capacity of the system to teach users and provide adequate follow-up, the inability to establish community support and capacity for self-care, lack of knowledge about adherence and effective interventions to improve it. ${ }^{14,23}$

3. Factors related to the physician. These factors have been shown to affect adherence in hypertension. They include good physician-patient relationships, willingness to treat hypertension from the point of dose evaluation and combination therapy and the degree of knowledge of the costs of medications and coverage forms. ${ }^{24}$

4. Factors related to the disease and health condition of the patient. The disease is also a relevant factor, as it has been observed that as the chronicity increases, the compliance with the treatment decreases. Poor adherence to prescribed regimens affects all age groups. This is a factor that influences therapeutic adherence, but, irregularly. The subjective perception of seriousness also influences, that means, if the patient realizes that the illness is serious and puts his or her life at risk; he or she will more accurately comply with the treatment. However, if the patient has minimal symptoms of the disease, he or she will adhere less to the treatment and, when the treatment is for preventive purposes, the same thing happens. ${ }^{14,25}$

5. Factors related to the therapy. Polytherapy, the complexity of the medical regimen, chronic and/or recurrent treatments, previous treatment failures of the patient, frequent changes in treatment, are associated with different tolerability profiles; the incomprehension of the therapeutic regimen, the cost of the medication, the pharmaceutical forms and/or containers of complex use. It has been proven that when a treatment is short and easy to follow, the patient has good adherence, which decreases when it is a long-term treatment, due to the different classes of antihypertensives. ${ }^{14,24}$

6. Factors related to the patient. It is important that patients follow the treatment to improve their health, they are aware of their illness and the importance of complying with pharmacological treatments and modifying their lifestyle. However, this is a problem that affects the patients, within these we can find: the lack of motivation in the patient to be healthy again, poor communication, carefree attitude towards the illness and/or the treatment, poor knowledge about the illness and/or the therapy, the lack of confidence in the efficacy of the treatment, the patient's perception that the illness is not very serious and finally, the ignorance about the consequences of the non-compliance. If patients are not aware of the chronic nature of the disease, or think that it is a trivial condition, they are less likely to adhere and persist with prescriptions. ${ }^{14,24,25}$

In recent years, a large number of therapeutic compliance interventions addressed to the training of health professionals, made by medical scientific societies and, to a lesser extent, by public bodies, which should have led to a significant decrease of non-compliance. Probably, multifactorial etiology of noncompliance makes harder to achieve a greater impact and, in the future, to reduce noncompliance, interventions should target not only health professionals, but also the hypertensive population and health decision makers. ${ }^{8}$

\section{Most affected population}

In an article on prevalence, it was reported that $48.5 \%$ of the men had total adherence; $37 \%$ of women were fully adherent to treatment; $61 \%$ of the latter had partial adherence and $2 \%$ had no adherence. ${ }^{19}$ Also, the ages of participants ranged from 31 to 69 years old; $71.4 \%$ of hypertensive patients were between 50 and 69 years old; in addition, participants in this age group had greater therapeutic adherence than those under-aged. Regarding occupation, housewives had a $38.33 \%$ adherence compared to retired people who had a $56 \%$ adherence. ${ }^{19}$

The Institute for Social Research, University of Michigan, conducted a research on antihypertensive adherence in 48 patients aged $35-87$ years old and found a directly proportional relationship: the older the person, the lower the drug adherence. ${ }^{26}$ In this study adherence was higher in the age groups of 40 to 45 years old and 45 to 50 years old. Kirscht concludes that at lower education and greater age, the lower the adherence as it is observed in the results of the present study: $34 \%$ had a primary education and $33 \%$ of these patients were between 40 and 50 years old. ${ }^{26}$

\section{Prevention of hypertension complications by complying with medical treatment}

In this research study, the majority of participants had less than 10 years with the disease evolution, this is an advantage because it can still avoid and/or delay the damage caused by the disease by strengthening adherence to treatment and medical indications. One of the aspects still unresolved is how to increase adherence. It is believed that, the best way to do it is by promoting health, education and by preventing comorbidities. ${ }^{19}$

In order for pharmacological therapies to be successful in fighting the referred diseases, they require therapeutic compliance, adherence to complementary guidelines related to lifestyle habits, the knowledge and the commitment of the patients with their health and the trust that is established with the treating professional. This set of factors, associated with each other, although of different natures, has a positive impact on the quality of life of the patient. ${ }^{20}$

The control of high blood pressure is crucial to avoid complications, patients with therapeutic adherence have a better control of blood pressure and this makes the difference at a long term. For this reason, programs must be created focused on each patient with the multidisciplinary commitment of all the staff that has to do with hypertensive patients in one way or another. 
Several studies have shown that to improve patient's awareness of hypertension to achieve compliance with the treatment, the patient must be aware of blood pressure levels as well as have a better understanding of the chronic nature of the disease, and that sometimes one can interpret it as asymptomatic patients, because of considering hypertension a silent enemy. ${ }^{19,24}$

\section{Conclusions}

When the prescribed treatment is not followed, patients are often blamed for it, in spite of having evidence proving that health professionals and health care systems can have a great influence on the patient's behavior in this regard. ${ }^{27}$

The WHO considers the lack of compliance of chronic treatments and their negative clinical and economic consequences a priority issue of public health. "It is essential that countries review and implement health care measures that are known for being able to reduce premature deaths from chronic diseases". ${ }^{27,28}$

Noncompliance is an important care problem that can affect patient's, and is one of the possible causes of treatment's failure.$^{27}$ It is necessary to raise more awareness of the control of hypertension. By having patients a good compliance or adherence to their treatment, enormous benefits are obtained both for the patient (avoiding cardiovascular complications) and for the health care system (costs for intrahospital stays). ${ }^{24}$

\section{References}

Arias-Albuja G, Perez-Ramos F. Valoración de la adherencia a la terapéutica prescrita y sus factores condicionantes en pacientes diagnosticados de hipertensión arterial sistémica esencial tratados en el Hospital Delfina Torres Viuda de Concha (tesis licenciatura) Quito: Pontifica Universidad Católica de Ecuador, Facultad de Medicina; 2014

Herrera-Guerra E. Adherencia al tratamiento en personas con hipertensión arterial. Av. Enferm. 2012; 30: 67-75.

Gutiérrez JP, Rivera-Dommarco J, Shamah-Levy, et al. Encuesta Nacional de Salud y Nutrición 2012. Resultados Nacionales. Cuernavaca, México: Instituto Nacional de Salud Pública, 2012: 1-200.

Organización Mundial de la Salud (OMS). Información General sobre la Hipertensión en el Mundo. Una enfermedad que mata en silencio, una crisis de salud pública mundial. OMS, 2013: 1-40.

Ingaramo RA, Vita N, Bendersky M, et al. Estudio Nacional sobre adherencia al tratamiento. Rev. Fed. Arg. Cardiol. 2005; 34: 104-111.

Libertad de los Ángeles MA, Grau-Abalo JA, Espinosa-Brito AD. Marco conceptual para la evaluación y mejora de la adherencia a los tratamientos médicos en enfermedades crónicas. Rev. Cubana de Salud Pública. 2014; 40: 225-238.

Vinaccia S, Quiceno JM, Fernández H, Gaviria AM, Chavarría F, Orozco O. Apoyo Social y Adherencia al Tratamiento Antihipertensivo en Pacientes con Diagnostico de Hipertensión Arterial. Informes Psicológicos. 2006; 8: 89-106.

Espinosa-García J, Martell-Claros N, Llerena-Ruiz A, Fernández-BergésGurrea D. Cumplimiento farmacológico en el tratamiento de la hipertensión arterial. Revisión de los estudios publicados entre los años 1975 y 2011. Semergen. 2012; 38: 292-300.

Martos-Méndez M. Análisis de la Satisfacción Vital, Salud y Apoyo Social en Pacientes con Hipertensión Arterial. Rev. Psicol. Salud 2016; 4: 24-59.

Zambrano R, Duitama JF, Posada JI, Flórez JF. Percepción de la adherencia a tratamientos en pacientes con factores de riesgo cardiovascular. Rev. Fac. Nac. Salud Pública. 2012; 30: 163-174.

Grau-Abalo J. Enfermedades crónicas no transmisibles: Un abordaje desde los factores psicosociales. Salud \& Soc. 2016; 7: 138-166.

D’Anello S. Cumplimiento del tratamiento médico: Aspectos psicosociales. In Aportes a la Psicología Social de la Salud. Ediciones Vicerrectorado Académico. Universidad de Los Andes. MéridaVenezuela. 2006: 181-198.
Varela-Arévalo MT. El reto de evaluar la adherencia al tratamiento en la hipertensión arterial. Pensamiento Psicológico. 2010; 7: 127-139.

Fernández-Pacheco N. Adherencia terapéutica pacientes con hipertensión arterial, dislipidemia y sobrepeso. (tesis licenciatura). España: Universidad de la Laguna; Facultad de Ciencias de la Salud; 2015.

Boza RA, Milanes F, Slater V, Garrigo L, Rivera CE. Patient noncompliance and overcompliance. Behavior patterns underlying failure to follow doctor's order. Postgrad Med. 1987; 81: 163-170.

Galperin J. Como entender la adherencia a tratamientos. Medifam. 1994; 4: 213-216.

Rothert ML. Physicians' and patients' judgments of compliance with a hypertensive regimen. Med Decis Making. 1982; 2: 179-95.

Castells M. Cumplimiento terapéutico. In Farmacología en enfermería. 2a ed. España: Elsevier. 2007: 570.

Maldonado-Reyes FJ, Vázquez-Martínez VH, Loera-Morales J, Ortega Padrón M. Prevalencia de adherencia terapéutica en pacientes hipertensos con el uso del cuestionario Martín-Bayarre-Grau. Aten Fam. 2016; 23: 48-52.

Bertoldo P, Ascar G, Campana Y, Martin T, Moretti M, Tiscornia L. Cumplimiento terapéutico en pacientes con enfermedades crónicas. Rev Cubana Farm. 2013; 47: 468-474.

Libertad-Martín A, Bayarre-Vea H, La Rosa-Matos Y, et al Cumplimiento e incumplimiento del tratamiento antihipertensivo desde la perspectiva del paciente. Rev Cubana Salud Pública. 2007; 33: 1-10.

Guerrero-Romero JF, Rodríguez-Morán M. Prevalencia de la hipertensión Arterial y factores asociados en la población rural marginada. Salud Pública Mex. 1998; 40: 339-346.

Ortiz-Domínguez ME, Garrido-Latorre F, Orozco R, Pineda-Pérez D, Rodríguez-Salgado M. Sistema de Protección Social en Salud y calidad de la atención de hipertensión arterial y diabetes mellitus en centros de salud. Salud Pública Mex. 2011; 53: 436-444.

Erdine S. Compliance with the Treatment of Hypertension: The Potential of Combination Therapy. J Clin Hypertens 2010; 12: 40-46.

Florez-Torres IE. Adherencia a tratamientos en pacientes con factores de riesgo cardiovascular. Av. Enferm. 2009; 27: 25-32.

Kirscht JP, Rosenstock IM. Patient adherence to antihypertensive medical regimens. J Community Health 1977; 3: 115-124.

Rodríguez-Chamorro MA, García-Jiménez E, Amariles P, Rodríguez Chamorro A, Faus MJ. Revisión de tests de medición del cumplimiento terapéutico utilizados en la práctica clínica. Aten Primaria. 2008; 40: 413-418.

Holguín L, Correa D, Arrivillaga M, Caceres D, Varela M. Adherencia al Tratamiento de hipertensión arterial: Efectividad de un programa de intervención biopsicosocial. Univ. Psychol. Bogotá (Colombia) 2006; 5: 535-547.

American Cancer Society [homepage on the Internet] 2017. Tasas de supervivencia del cáncer de seno. Atlanta, Georgia, Estados Unidos [Last Medical Review: June 1, 2016] [Last Revised: August 18, 2016]. Available from: https://www.cancer.org/es/cancer/cancer-deseno/comprension-de-un-diagnostico-de-cancer-de-seno/tasas-desupervivencia-del-cancer-de-seno.html.

Sánchez G, Niño CG, Estupiñán C. Factores asociados con el tratamiento oportuno de mujeres con cáncer de mama apoyadas por una organización no gubernamental en Bogotá. Biomédica. 2015; 35: $505-$ 512.

Jon DE, Shaw K, Williams B, et al. The role of primary care in early detection and follow-up of cancer. Nat. Rev. Clin. Oncol. 2014; 11 : $38-48$.

Vahit O, Boylu S, Ok E, et al. Factors affecting breast cancer treatment delay in Turkey: a study from Turkish Federation of Breast Diseases Societies. Eur. J. Public. Health. 2015; 25: 9-14.

Unger-Saldaña K, Infante-Castañeda CB. Breast cancer delay: a grounded model of help-seeking behaviour. Soc. Sci. Med. 2011; 72: 1096-104.

Weller D, Vedsted P, Rubin G, et al. The Aarhus statement: improving design and reporting of studies on early cancer diagnosis. Br. J. Cancer 2012; 106: 1262-7.

Mignini L, Ramos S, Pesce V, et al. Demoras en el proceso de atención de pacientes con cáncer de mama en dos hospitales públicos de la provincia de Santa Fe. Rev. Argent. Salud Pública, 2016; 7: 21-26.

Khan MA, Hanif S, Igbal S, Shahzad MF, Shafique S, Khan MT. Presentation delay in breast cancer patients and its association with sociodemographic factors in North Pakistan. Chin. J. Cancer Res. 2015; $27: 288-293$ 